\title{
Sanat ve Öğretmen: Öğretmen Adaylarının Sanat ile Bir-Aradalığı
}

\section{Art and Teaching: Coexistence of Prospective Teachers with Art}

\author{
Peyruze Rana ÇETINKAYA ，Dr. Araştırma Görevlisi, Dokuz Eylül Üniversitesi, Buca Eğitim Fakültesi, İzmir/TÜRKiYE, \\ peyruze.simsek@deu.edu.tr
}

Sermin BiLEN , Dr. Öğretim Üyesi, , Dokuz Eylül Üniversitesi, Buca Eğitim Fakültesi, İzmir/TÜRKiYE, sermin.bilen@deu.edu.tr

\begin{abstract}
Çetinkaya, P. R. ve Bilen, S. (2021). Sanat ve Öğretmen: Öğretmen Adaylarının Sanat ile Bir-Aradalığı. Batı Anadolu Eğitim Bilimleri Dergisi, 12 (1), 276-292.
\end{abstract}

Geliş tarihi: 27.01.2021

Kabul tarihi: 27.05 .2021

Yayımlanma tarihi: 28.06.2021

Öz. Yaratıcı ve üretici düşünme becerisinin en önemli destekleyicilerinden olan sanat, yaşamı anlamlandıran ve tekdüzelikten çıkaran bir güç taşır. Sanatın gücü, her alandaki çağdaş öğretmenlerin öğrencilerine rol model olmalarıyla anlam kazanır; sanatla yaşamları zenginleşmiş bireylerin yetiştirilmesine ve estetik bir toplum oluşumuna temel oluşturur. Yalnızca alan ve meslek bilgisi ile sınırlı kalmayıp kültürel boyutta da kendisini yetiştiren, sanatın gücünden beslenerek dünyaya çok yönlü bir bakış açısı geliştirebilen öğretmenlerin, ideal bir rol model olma olasılığının yüksek olduğu söylenebilir. Bu bağlamda bu çalışmada, farklı disiplinlerdeki öğretmen adaylarının sanat ile olan ilişkilerinin ve sanata olan bakış açılarının ne olduğu sorusuna odaklanılmıştır. Çalışmanın katılımcılarını Dokuz Eylül Üniversitesi Buca Eğitim Fakültesi'nin, İngiliz Dili Eğitimi, Alman Dili Eğitimi, Fransız Dili Eğitimi ve Müzik Eğitimi Anabilim dallarında son sınıfta öğrenimine devam eden 115 öğretmen adayı oluşturmuştur. Tarama modelinin kullanıldığı çalışmada veriler, kapalı ve açık uçlu sorulardan oluşan soru formu ile toplanmıştır. Kapalı sorulardan elde edilen veriler için betimleyici istatistik kullanılmış, açık uçlu sorudan elde edilen veriler için ise içerik analizi uygulanmıştır. Elde edilen bulgular, farklı alanlarda öğrenim görmekte olan öğretmen adaylarının, farklı sanat dallarıyla olan yeterince güçıü ilişki kuramadıkları ve genel anlamda sanatı yaşamlarının bir parçası haline getiremedikleri yönündedir.

Anahtar Kelimeler: Öğretmen eğitimi, Sanat ve eğitim, Sanat ve kültür.

\begin{abstract}
Art, which is one of the most important supporters of creative and productive thinking skills, carries a power that makes life meaningful and uneven. The power of art gains significance as contemporary teachers in every field are role models for their students. It serves to raise individuals whose lives have been enriched with art and to create an aesthetic society. It can be said that teachers who are not only limited to their field and profession knowledge but also train themselves in a cultural dimension and who can develop a multi-faceted perspective to the world and benefit from power of art, are likely to be an ideal role model. In this context, this study focuses on the question of what are the relationships of prospective teachers in different disciplines with art and their perspective on art. The participants of the study were 115 prospective teachers from the Dokuz Eylul University, Buca Faculty of Education who continued their education as seniors in the Departments of English Language Education, German Language Education, French Language Education and Music Education. Descriptive statistics were used for the data obtained from closed questions and content analysis was applied for the data obtained from the open-ended questions. The findings show that the relations of the prospective teachers studying in different fields are not able to relate strongly enough to different branches of art and cannot make art a part of their lives.
\end{abstract}

Keywords: Teacher education, Art and teaching, Art and culture. 


\section{Extended Abstract}

Introduction. Art is the most important guide in our searching for ourselves and the meaning of life. Life itself is an artistic texture with endless possibilities of creation and the potential to create aesthetic experiences. In this context, societies that improve with art can create aesthetic societies of the future, as in Schiller's ideas.

In the modern era, the searching for solutions to the need for individuals who have productive and creative thinking skills always comes to the same place: Qualified education. The most indispensable supporter of revealing and developing the potential of human existence is a qualified education. The indispensable element of qualified education is qualified teachers. A well-trained teacher is expected to have cultural knowledge as well as proficiency in pedagogical content knowledge.

In the information societies of the information age, the teacher is no longer the person presenting the information, but the person teaching to learn. In all this intense flow of information, it has become a necessity for the teacher her/himself to continue to learn and develop throughout her/his life. The teacher purposes to guide people and society in order to create meaningful lives. A guide interested in art, which is one of the basic unit of a meaningful life, is undoubtedly the most ideal for this purpose. In order to reach this ideal, it can be said that it is a necessity to include the contents related to art and aesthetics in teacher education. In this context, the study focused on this main question: What is the relationship and perspective of prospective teachers having education in different fields of teaching to art?

In this study, it is aimed to reveal the relationships and approaches of teacher candidates, who are educated in different fields of teaching, with branches of art and the art activities. In order to benefit from the constructive power of art, the teacher is expected to develop intimacy with artistic actions. Based on this, it is thought that the study is important in terms of pointing to the necessity of designing teacher training programs in a framework that is integrated with the arts and that this way, internal and professional motivation of teacher candidates can also be supported.

Method. This study is in the survey model carried out to determine the habits of teacher candidates to participate in culture-art activities and what contributions art has to their lives. The participants of the study were 115 teacher candidates who continued their education in the departments of English Language Education, German Language Education, French Language Education and Music Education of Dokuz Eylul University, Buca Faculty of Education in the fall semester of the 2017-2018 academic year.

As a data collection tool, a questionnaire consisting of 9 closed and 1 open-ended questions and a total of 10 questions developed by the researcher was used in order to determine the relationships of pre-service teachers with art. It used frequency and percentage for the analysis of closed-ended questions, and content analysis for the analysis of open-ended question.

Results. Findings were divided into two as descriptive statistics and findings related to content analysis. First, frequency and percentage values are given in the following headings to describe the frequency of prospective teachers' attendance at artistic activities, their association with art and their life habits related to art.

- Watching concert events

- Attending amateur art events

- Watching theatrical performances

- Visiting art exhibitions (painting, sculpture, photography and the other visual arts)

- Watching opera, ballet and dance performances

- Reading literary works

- Attending conversations in literature, poetry and philosophy

According to statistics, it has been found $53 \%$ of the participating teacher candidates attend concert activities once a year or not at all, $30 \%$ do not attend an amateur course in any art field, $82 \%$ watch a theatrical performance once a year or not at all, $\% 88$ of them visit a visual art exhibition once 
a year or not at all, $89 \%$ watch opera / ballet / dance performance once a year or none at all, and $90 \%$ attend a literature / philosophy / poetry once a year or none at all.

When the answers given to the open-ended question were examined with content analysis, three themes emerged:

1. The support of the arts for intellectual, spiritual and personal development

2. The support of the arts for cultural, social and professional development

3. The contribution of art to the increase of the quality of teaching and humanity

Discussion and Conclusion. In order to provide a qualified learning environment, it is important for the educators to handle science and art, professional knowledge and artistic hobbies with a holistic approach rather than separating them from each other. It can be said that it is important to get more art into their personal and professional lives and then into the lives of the generations they have grown up.

The results of the study are that although participants have continued their education in Turkey's third largest city and an art city where many artistic events have been accessible and they have thought that art has had multiple contributions, they could not make enough space to different fields of art in their lives and their connection with art was superfacial. A teacher education integrated with the arts will extend the connection with the arts beyond individual endeavors. Teachers of future, who will become role models, are expected to equip themselves and their students with art in order to raise generations who will look at the world from a different perspective. 


\section{Giriş}

İ̧̧üdüsel ve pragmatik yönelimler barındıran günlük yaşamlarımızdaki aynılık ve nesne odaklılık, yaşam olgusuyla çelişircesine, canlılı̆ın yitirildiği bir süreğenlik taşır. Bu ölgün yanlar, ancak sanatla yaşam bulabilir. İlhan'ın (1997: 17) vurguladığı gibi, "Sanat, düşünmeye ve imgeleme ait oluşuyla doğrudan doğruya özgürlüğün ve özgürleşmenin nesnelleştiği alandır." Özümüzü ve anlamı arayışımızdaki en önemli rehberdir.

İçinde barındırdığı sonsuz yaratım olanakları ve estetik duygulanım oluşturma potansiyeli ile yaşamın kendisi sanatsal bir dokudur. Sanat, yaşamın oluşuna karışmıştır; yaşamda içkindir. Bu sanatsal dokunun içinde, sanatla birlikte yol alan bireyler ve toplumlar, güzel olanın hem duyusal hem düşünsel anlamda yarattığı bütünsel oluşa varabilir. Schiller'in (2020: 123-124) belirttiği gibi, "yalnızca güzel, iletişim toplumunu geliştirir, çünkü herkesin ortak yanıyla ilgilidir."

Arnheim (2007), sanat alanlarını algısal bileşeni destekleyen en önemli araçlar olarak niteler ve algısal bileşenin olmadığı bir alanda üretici bir düşünme biçimi geliştirmenin olanaksızlığından söz eder.

Modern çağda, üreten, yapıcı ve yaratıcı bireylere artan gereksinime çözüm arayışımız hep aynı yere çıkar: Nitelikli eğitim. "İnsanın biyolojik bir varlıktan kültürel bir varlığa dönüşümünü sağlayan en önemli güç eğitimdir." (Özcan, 2011: 18). İnsanın varoluşunda taşıdığı gizilgücü ortaya çıkarabilmesi ve geliştirebilmesinin en vazgeçilmez destekçisi nitelikli bir eğitimdir. İnsan, oldukça engin bir yaratma gücüyle dünyaya gelir ve bu yaratıcı gücün gelişimi, yetişimi için bir zorunluluk olan "Kalkınmanın ve çağdaşlaşmanın en önemli girdisi iyi yetiştirilmiş insan gücüdür. Nitelikli insan gücünü yetiştiren ise, nitelikli öğretmendir." (Şahin, 2011: 240). Bu, meslekte her anlamda üstün olma halinin sağlayıcıları arasında, alan bilgisi ve öğretmenlik meslek bilgisinin yanı sıra, genel kültür bilgisi, diğer bir deyişle kültürel bilgi birikimi de bulunmaktadır.

İçinde yaşadığımız bilgi çağında, bilgi edinme yollarının çokluğu, kolay erişilebilirliği ve çoğunlukla kontrol edilemezliği, öğretmen kimliğini geleneksel çizgisinin dışına çıkarmış, yeni dünyada öğretmen tanımını yeniden şekillendirmeyi zorunlu kılmışır. Özcan'ın (2011) belirttiği gibi, eleştirel yaklaşıma sahip, bilgi ve beceri düzeyi yüksek, doğru bilgiye ulaşma yollarını bilen ve ulaşmakla kalmayıp aynı zamanda bilgiyi üreten öğretmen, yeni nesle daha etkili biçimde rehberlik edebilir. Bilgi çağının bilgi toplumlarında, öğretmen artık bilgiyi sunan kişi olmaktan çıkıp öğrenmeyi öğreten ve kendisi de tüm bu yoğun bilgi akışı içinde yaşam boyu öğrenmeye ve gelişmeye devam eden bir kimliğe bürünmüştür.

Schiller'in (2020) modern insan betimlemesinde parçalanmışlık vurgusu göze çarpar. Bu parçalanmışlığın ana nedeni olarak, Schiller, insanın duygu dünyası ile madde dünyası arasındaki çatışmayı öne sürer. Hem insanlar arasındaki bağlarda, hem de kişinin kendisi ile kurduğu bağda bütünlük yoksunluğu olduğunu belirtir. Bu ve daha pek çok çıkmazı aşabilmek için estetik eğitimini bir çıkış yolu olarak işaret eder. Estetik yaklaşımlar geliştirebilmek için de, sanatın gücünden ve aracılı̆ından yararlanmak önem kazanır. Estetik arayışın, sadece sanatı meslek edinen belli bir toplulukla sınırlı kalmaması adına, herkes için sanat anlayışıyla yol alma gerekliliği doğar.

Read (1967), tüm insanların yaratıcılıkla bezenmiş olarak doğduğunu, ancak daha sonra içinde yaşadığımız ve kabullendiğimiz toplumsal normların, estetik içtepilerimizi özgürce sunmaktan bizi alıkoyduğunu ve bu nedenle ruhsal anlamda biçimsizleştiğimizi öne sürer. Buna sebep olan sürecin, geleneksel eğitim süreci olduğunu ve bu anlayışta bireyin, toplumsal değerleri ve kültürel kalıntıları nesiller boyunca taşıyacak bir zincirin halkası olarak ele alındığını düşünür. Benzer biçimde Robinson 
(2008: 73) şöyle der: "Çok sayıda insan, eğitim kurumlarından gerçek entelektüel güçleri hakkında hiçbir fikirleri olmadan mezun oluyor."

Öğreten kişi, öğretme sanatını icra eden kişidir. İnsana ve nihayetinde topluma, anlamlı yaşantılar yaratma yolunda rehberlik eder. Anlamlı bir yaşantının yapıtaşlarından olan sanat ile yoğrulmuş bir rehber, kuşkusuz bu amaç için en ideal olandır. Bu ideale ulaşabilmek için, öğretmen eğitiminde sanata ve estetiğe ilişkin içeriklere etraflıca yer verilmesinin bir gereklilik olduğu söylenebilir. Özellikle sanat eğitimi ve sanatla iç içe değerlendirilebilecek dil eğitimi alanlarında öğrenim gören eğitimci adaylarının, sanatın ve dilin gücünü daha etkin biçimde yansıtabilmeleri için farklı sanat alanlarıyla etkileşimli yetişmeleri beklenir.

Bu bağlamda, çalışma şu ana soruya odaklanmıştır: Farklı disiplinlerdeki öğretmen adaylarının sanat ile olan ilişkisi ve sanata bakış açısı nedir?

\section{Amaç ve Önem}

Çalışmada, farklı öğretmenlik alanlarında eğitim alan öğretmen adaylarının sanat dallarıyla ve sanatsal aktivitelerle olan ilişkilerini ve sanata olan yaklaşımlarını ortaya koymak amaçlanmıştır. Ufuk açan ve farklı bakış açıları sunma misyonu edinen çağdaş bir eğitimcinin, bu misyonu gerçekleştirebilmesi için sadece kendi branşının sınırlarında kalmanın ötesinde, başka alanlarla entegre biçimde yol alması gerekliliği söz konusudur. Bu anlamda sanat, oldukça önemli bir rehberdir; sanatın ufuk açan gücünden yararlanabilmesi için, öğretmenin sanatsal eylemlerle iç içe olması beklenir. Buradan yola çıkarak, çalışmanın, öğretmen yetiştirme programlarının da sanatla bütünleşik bir çerçeveye oturtulması gerekliliğine ve bu sayede öğretmen adaylarında içsel ve mesleki motivasyonun da desteklenebileceği fikrine ışık tutması bakımından önem taşıdığı düşünülmektedir.

\section{Yöntem}

Bu çalışma, öğretmen adaylarııın kültür-sanat aktivitelerine katılım alışkanlıklarını ve sanatın yaşamlarına ne gibi katkıları olduğunu belirlemek amacı taşıyan, tarama modelinde bir çalışmadır.

Günlük yaşamda her alanda karşımıza çıkan tarama araştırmaları, araştırma yapılan grubun özelliklerini ölçmek veya var olan durumu ortaya çıkarmak için kullanılmaktadır. Tarama araştırmaları, anket ya da görüşme protokollerine dayanan deneysel olmayan bir araştırma yöntemi olarak da bilinir (Atalmış, 2019: 97).

Veri toplama aracı olarak, öğretmen adaylarının sanatla olan ilişkilerini saptayabilmek için araştırmacılar tarafından geliştirilen 9 kapalı ve 1 açık uçlu sorudan oluşan, toplam 10 sorudan oluşan bir soru formu kullanılmıştır.

Kapalı uçlu soruların analizi için frekans ve yüzde, açık uçlu sorunun analizi için ise içerik analizi kullanmıştır. İçerik analizinde, yazılı bir kaynak ya da iletişim materyalindeki mesajların sayılara dökülmesi, incelenmesi ve yorumlanması söz konusudur (Arıkan, 2005). Nitel içerik analizi, iletişim kaynağındaki içeriğin, kodlama yoluyla ve ana temalara ulaşmak için kodları kategorize etme aracılığıyla öznel biçimde yorumlanmasıdır (Cansoy\&Türkoğlu, 2019). Öncelikle içerik, kod haline getirilecek kavramsal parçalara bölünerek analiz edilir ve analizin devamında kategoriler (temalar) oluşturulur. Anahtar temalar, bu kodlamalar sınıflandırıldıktan sonra ortaya çıkar. Elde edilen sonuçlar, metindeki ya da veri kaynağındaki mesajlar hakkında çıkarımlar yapmak için kullanılır. Daha sonra, kodlama şemasındaki tekrar sıklığı göz önüne alınarak nicel analize geçilir ve nihai sonuçlar istatistikler kullanılarak açıklanır (Wilson, 2011). Çalışmada, açık uçlu soruya verilen yanıtlarda sık tekrarlanan ve 
bir anlam taşıyan sözcük ve kavramlar, kod listesini oluşturmuştur. Bu kavramlar birbirleriyle olan ilişkileri doğrultusunda kategorize edilmiş ve buradan hareketle temalar altında toplanmıştır.

\section{Katılımcılar}

Çalışmanın katılımcılarını 2017-2018 öğretim dönemi güz yarıyılında, Dokuz Eylül Üniversitesi Buca Eğitim Fakültesi'nin, İngiliz Dili Eğitimi, Alman Dili Eğitimi, Fransız Dili Eğitimi ve Müzik Eğitimi Anabilim dallarında son sınıfta öğrenimine devam eden 115 öğretmen adayı oluşturmuş̧tur. Çalışmanın katılımcıları belirlenirken, dil eğitimi alanları yabancı dil eğitimi ile sanat eğitimi alanları ise müzik eğitimi ile sınırlandırılmıştır. Çalışmada içerik analizi için, 115 katılımcıdan $25^{\prime}$ inin açık uçlu soruya yanıt vermemiş olması nedeniyle 90 katııımının görüşleri değerlendirmeye alınmıştır. Katılımcıların frekans ve yüzdelere göre dağılımları Tablo 1'de yer almaktadır.

Tablo 1.

Katılımcıların frekans ve yüzdelere göre dağılımları

\begin{tabular}{lrr}
\hline Anabilim Dalı & $\boldsymbol{f}$ & $\%$ \\
\hline Ingiliz Dili Eğitimi & 53 & 46 \\
Müzik Eğitimi & 26 & 23 \\
Fransız Dili Eğitimi & 22 & 19 \\
Alman Dili Eğitimi & 14 & 12 \\
\hline Toplam & 115 & 100 \\
\hline
\end{tabular}

Tablo 1'de görüldüğü gibi, katılımcıların \%46'sı İngiliz Dili Eğitimi, \% 23’ü Müzik Eğitimi, \%19'u Fransız Dili Eğitimi ve \%12'si Alman Dili Eğitimi öğrencileridir.

\section{Bulgular}

Bu bölümde çalışma verilerinden elde edilen bulgular ve bulgulara ilişkin yorumlar, soru formunda yer alan kapalı sorular için betimleyici istatistik bölümünde ve açık uçlu soru için yapılan içerik analizi bölümünde ayrı olarak ele alınmıştır.

\section{Betimleyici İstatistiklere İlişkin Bulgular}

Öğretmen adaylarının sanatla bir-aradalığını irdelemek üzere belirlenmiş başılılar altında verdikleri yanıtlara ilişkin betimleyici istatistik bulguları aşağıda tablolaştırılmıştır.

Katılımcıların konser etkinliklerine katılım sıklıklarını betimleyen istatistiğe Tablo 2' de yer verilmiştir.

Tablo 2.

Konser etkinliklerine katılım sıklığına ilişkin betimsel istatistik

\begin{tabular}{lrr}
\hline Konser etkinliklerine katılım sıklığı & $\boldsymbol{f}$ & $\boldsymbol{\%}$ \\
\hline Hiç & 15 & 13 \\
Yılda bir kez & 46 & 40 \\
Yılda birkaç kez & 33 & 29 \\
Ayda bir kez & 20 & 17 \\
Haftada bir kez & 1 & 1 \\
\hline
\end{tabular}


Tablo 2' de görüldüğü gibi, öğretmen adaylarının \%13'ü hiç konsere gitmediğini, \%40'ı yılda bir kez, \% 29'u yılda birkaç kez, \%17'si ayda bir kez ve \%1'i haftada bir kez katıldığını belirtmiştir. Çalışmanın, Türkiye'nin üçüncü büyükşehri ve kültürel-sanatsal bir başşehir olan İzmir ilinde gerçekleştirildiği göz önüne alındığında, türü fark etmeksizin bir müzik dinletisine hiç katılım göstermeyen öğretmen adaylarının varlığı dikkat çekmektedir. Bunun yanında, farklı müzik türlerinde pek çok dinleti, konser ve etkinliğin, pek çok farklı ulaşılabilirlikteki mekan ve olanaklarda gerçekleştirildiği bilinen bir şehirde, katılımcıların \%40'ının yalnızca yılda bir kez konser etkinliğine katıldıklarını, \%13'ünün ise konser dinlemediklerini ifade etmiş olmaları, konser salonlarının etkileyici atmosferinden ve müziğin derin anlatım gücünden yoksun kaldıklarını düşündürmektedir.

Katılımcıların bireysel olarak herhangi bir sanat eğitimi alıp almadıklarına alıp almadıklarına ilişkin betimsel istatistiğe Tablo 3'te yer verilmiştir.

Tablo 3.

Amatör sanat atölyelerine katılıma ilişkin betimsel istatistik

\begin{tabular}{lrr}
\hline Amatör sanat atölyelerine katılım sıklığı & $\boldsymbol{f}$ & $\boldsymbol{\%}$ \\
\hline Müzik & 50 & 43 \\
Dans & 30 & 26 \\
Görsel Sanatlar & 40 & 35 \\
Diğer & 6 & 5 \\
Hiç & 35 & 30 \\
\hline
\end{tabular}

Tablo 3'te görüldüğü gibi, öğretmen adaylarının \%30'u hiçbir sanatsal eğitime katılmadığını, \% 43'ü müzik, \%26'sı dans, \%35'i görsel sanatlar (resim, fotoğrafçılık, heykel, seramik, el sanatları) ve \%5'i diğer sanat eğitimlerine katıldığını belirtmiştir. Bireysel gelişim ve donanımın yanı sıra mesleki yeterliliğe ve motivasyona da sağlayacağı katkı düşünüldüğünde, bir eğitimcinin sanat dallarından en az biriyle bir arada olması ve kendini ifade aracı olarak sanat dallarından birini benimsemesi önem taşır. Katılımcıların bir kısmının birden çok sanat alanıyla ilgili oluşu beklentilere olumlu yanıt vermektedir. Diğer yandan öğretmen adaylarının \%30'unun hiçbir sanat alanıyla ilgilenmediklerini belirtmiş olmaları dikkat çekicidir.

Katılımcıların tiyatro oyunu izleme sıklıklarını betimleyen istatistiğe Tablo 4'te yer verilmiştir.

Tablo 4.

Tiyatro etkinliklere katılım sıklığına ilişkin betimsel istatistik

\begin{tabular}{lrr}
\hline Tiyatro izleme & $\boldsymbol{f}$ & $\%$ \\
\hline Hiç & 37 & 32 \\
Yılda bir kez & 57 & 50 \\
Yılda birkaç kez & 15 & 13 \\
Ayda bir kez & 5 & 4 \\
Haftada bir kez & 1 & 1 \\
\hline
\end{tabular}

Tablo 4'te görüldüğü gibi, öğretmen adaylarının \%32'si hiç tiyatro oyunu izlemediğini, \%50'si yılda bir kez, \% 13'ü yılda birkaç kez, \%4'ü ayda bir kez ve \%1'i haftada bir kez tiyatro izlediğini belirtmiştir. Tiyatro, bireysel ve toplumsal ölçekte insana ve yaşama dair her oluşu, yaşantıyı ve sorunu gözler önüne serebilme ve izleyicilerini düşündürüp yüzleştirebilme gücüyle, belki de tüm sanat dalları içinde en yoğun dönüştürme gücüne sahip alandır. Öğretme misyonu edinmiş bir bireyin, hem bireysel, hem toplumsal yaşantılara ilişkin daha derin bir farkındalığının olması beklenir. Tiyatronun bu farkındalığı derinleştirme gücü göz önünde bulundurulduğunda, öğretmen adaylarının \%32'sinin hiç 
tiyatro oyunu izlemediğini, \%50'sinin de yılda yalnızca bir tiyatro oyunu izlediğini ifade etmiş olmaları, tiyatronun bu gücünden yeterince yararlanamayacakları şeklinde yorumlanabilir.

Katılımcıların resim, heykel, fotoğraf ve diğer görsel sanat sergilerine katılım sıklığını betimleyen bilgilere Tablo 5'te yer verilmiştir.

Tablo 5 .

Sergilere katılım sıklı̆̆ına ilişkin betimsel istatistik

\begin{tabular}{lrr}
\hline Sergi ziyareti & $\boldsymbol{f}$ & $\%$ \\
\hline Hiç & 47 & 41 \\
Yılda bir kez & 54 & 47 \\
Yılda birkaç kez & 9 & 8 \\
Ayda bir kez & 4 & 3 \\
Haftada bir kez & 1 & 1 \\
\hline
\end{tabular}

Tablo 5'te görüldüğü gibi, öğretmen adaylarının \% 41'i resim, heykel, fotoğraf ve diğer görsel sanat sergilerine hiç katılmadığını, \%47'si yılda bir kez, \%8'i yılda birkaç kez, \%3'ü ayda bir kez ve \%1'i haftada bir kez sergi ziyaretinde bulunduğunu ifade etmiştir. Görsel sanatlar, barındırdıkları yoğun imgelem gücü aracılığıyla yaratıcı düşünme ve eylemlerin önemli bir destekleyicisidir. Kişinin yaşantısına, çevresine ve doğaya ilişkin estetik bir yaklaşım benimsemesinde oldukça önemli bir rol oynar. Bireylerin estetik değerlere ve yaşantılara sahip olması ve bu sayede estetik toplum idealine ulaşılması yolunda görsel sanatların olumlu yönde itici gücü düşünüldüğünde, öğretmen adaylarının $\% 41$ 'nin hiç sergi ziyaretinde bulunmadıklarını, \%47'sinin de yılda sadece bir kez sergi ziyaret ettiklerini ifade etmiş olmaları, önemli bir çoğunluğun, görsel sanatların yaşamı zenginleştirme gücünden büyük ölçüde yoksun kaldıkları şeklinde yorumlanabilir.

Katılımcıların opera, bale ve dans temsillerine katılım sıklığını betimleyen bilgilere Tablo $6^{\prime}$ da yer verilmiştir.

Tablo 6.

Opera/bale/dans temsillerine katııım sıklı̆ı̆ı ilişkin betimsel istatistik

\begin{tabular}{lrr}
\hline $\begin{array}{l}\text { Opera/bale/dans temsili } \\
\text { izleme }\end{array}$ & $f$ & $\%$ \\
\hline Hiç & 57 & 50 \\
Yılda bir kez & 45 & 39 \\
Yılda birkaç kez & 6 & 5 \\
Ayda bir kez & 7 & 6 \\
Haftada bir kez & - & - \\
\hline
\end{tabular}

Tablo 6'da görüldüğü gibi, öğretmen adaylarının \%50'si opera-bale-dans temsillerine hiç katılmadığını, \% 39'u yılda bir kez, \%5'i yılda birkaç kez, \%6'sı ayda bir kez katıldığını belirtmiştir. Haftada bir opera-bale-dans temsiline katılım sağlayan hiç katılımcı yoktur. Sahne sanatlarına ilişkin pek çok ögeyi barındıran bütünleşik bir alan olan opera ve bale, kültürel dokuları derinlemesine yansıtabilen evrensel boyutta bir anlatım sunar. Dünya dillerini belki de en estetik biçimde sergileyen çok boyutlu bir sanat dalı olan opera; kültürel, dönemsel ve etnik yapılara ilişkin zengin bir görsel anlatı sunan dans; müziğin, dekorun, mimik-jestlerin ve hareketin bir harmanı olan bale sanatlarının, bütüncül bir estetik algıya ve yorumlama becerisine kattıkları düşünüldüğünde, öğretmen adaylarının \%50'sinin hiç opera/bale/dans temsili izlemediklerini, \%39'unun da yılda yalnızca bir kez temsil izlediklerini ifade etmelerinin, bütüncül bir estetik tavır geliştirebilme yolunda önemli bir eksiği vurguladığı düşünülebilir. 
Katılımcıların edebi eser okuma alışkanlıklarına ilişkin betimsel bilgilere Tablo 7'de yer verilmiştir.

Tablo 7.

Edebi eser okuma sıklığına ilişkin betimsel istatistik

\begin{tabular}{lrr}
\hline Edebi eser okuma & $\mathbf{f}$ & \% \\
\hline Hiç & 3 & 3 \\
Yılda bir kitap & 14 & 12 \\
Yılda birkaç kitap & 14 & 12 \\
Ayda bir kitap & 45 & 39 \\
Haftada bir kitap & 39 & 34 \\
\hline
\end{tabular}

Tablo 7'de görüldüğü gibi, öğretmen adaylarının \%3'ü hiç edebi eser okumadığını, \%12'si yılda bir kitap, \%12'si yılda birkaç kitap, \%39'u ayda bir kitap, \%34'ü haftada bir kitap okuduğunu belirtmiştir. Hiç kitap okumadığını belirten \%3 ve yılda bir ya da birkaç kitap okuduğunu belirten toplamda \%24'lük kesim dikkat çekici görünmese de, katılımcıların dil ve sanat eğitimi alanlarında öğretmen adayı oldukları göz önüne alındığında azımsanması güçtür. Kitap okumanın, öğretmenliği meslek edinmeyi seçen bireylerde bir alışkanlık haline gelmiş olması beklenebilir. Okuma oranı ne kadar çoğalırsa, farklı bakış açıları ve açık fikirlilik de o kadar da çoğalacaktır.

Katılımcıların edebiyat, felsefe ve şiir söyleşilerine katılım sıklığına ilişkin betimsel bilgilere Tablo 8'de yer verilmiştir.

Tablo 8.

Edebiyat, felsefe ve şiir söyleşilerine katılma sıklığına ilişkin betimsel istatistik

\begin{tabular}{lrr}
\hline Söyleşiye katılma & $\boldsymbol{f}$ & $\%$ \\
\hline Hiç & 65 & 57 \\
Yılda bir kez & 38 & 33 \\
Yılda birkaç kez & 6 & 5 \\
Ayda bir kez & 6 & 5 \\
Haftada bir kez & - & - \\
\hline
\end{tabular}

Tablo 8'de görüldüğü gibi, öğretmen adaylarının $\% 57$ 'si hiç edebiyat, şiir ve felsefe söyleşilerine katılmadığını, \%33'ü yılda bir söyleşiye, \%5'i yılda birkaç söyleşiye, \%5'i ayda bir söyleşiye katıldığını belirtmiştir. Haftada bir söyleşiye katılan hiç katılımcı yoktur. Kültür aktarımının özünü oluşturan edebiyata, bireysel ve toplumsal yaşamı anlamlandırmada etkin rol oynayan şiire ve hayatın, benliğimizin ve şeylerin anlamını arayışımızın temelindeki felsefi düşünmeye ilişkin deneyimlerin paylaşıldığı, fikirlerin ifade edildiği, bu süreçlere ilişkin bilgilerin aktarıldığı söyleşi etkinliklerine, öğretmen adaylarının \%57'si hiç katılmadıklarını ifade etmişlerdir. Katılımcıların \%77'sinin yabancı dil eğitimi alanlarında \%23'ünün de sanat eğitimi alanında öğrenim gördükleri düşünüldüğünde, kültürel birikimin ve paylaşımın sağlandığı önemli bir alandan yoksun kaldıkları düşünülebilir.

\section{İçerik Analizine ilişkin Bulgular}

Öğretmen adaylarının, sanatla bir arada olmanın mesleki yaşantılarına katkısına ilişkin açık uçlu soruya verdikleri yanıtlar analiz edildiğinde üç tema ortaya çıkmıştır. Bunlar:

1. Sanatın düşünsel, ruhsal ve kişisel gelişime desteği,

2. Sanatın kültürel, sosyal ve mesleki gelişime desteği,

3. Sanatın, öğretme eyleminin niteliğinin yükselmesine ve insanlığa katkısıdır. 
Her bir temayı oluşturan, toplamda 10 alt temaya ilişkin betimsel istatistik bulguları tablolaştırılmış ve her alt temaya ilişkin örnek cümleler verilmiştir.

\section{Sanatın Düşünsel, Ruhsal ve Kişisel Gelişime Desteği Temasına ilişskin Bulgu, Yorum ve Örnek cümleler}

Birinci temayı oluşturan dört alt temaya ilişkin betimsel bilgilere Tablo 9'da yer verilmiştir.

Tablo 9.

Sanatın düşünsel, ruhsal ve kişisel gelişime desteğine ilişkin yüzde ve frekans değerleri

\begin{tabular}{llrr}
\hline Tema & Alt tema & $f$ & $\%$ \\
\hline \multirow{3}{*}{$\begin{array}{l}\text { Sanatın düşünsel, ruhsal } \\
\text { ve kişisel geliş̧̇me desteği }\end{array}$} & Farklı bir bakış açısı ve problem çözme & 41 & 46 \\
& Yaşam enerjisi, mutluluk, pozitiflik ve ruhsal dinginlik & 18 & 20 \\
& Kişisel gelişim ve kişisel kazanımlar & 25 & 28 \\
& Yaratıcılık ve estetik düşünme & 10 & 11 \\
\hline
\end{tabular}

Tablo 9'da görüldüğü üzere, \%46 sanatla bir-aradalığın "farklı bir bakış açısı kazandırdığı" ve "problem çözme becerisini arttırdığı" yönünde, \%28 "kişisel gelişim ve kazanımlara katkısı" yönünde, \%20 "yaşam enerjisi, mutluluk, pozitifliği arttırdığı ve ruhsal dinginlik sağladığı" yönünde ve \%11 "yaratıcılığı ve estetik düşünme becerisini arttırdığı" yönünde görüş bildirilmiştir. ilgili kategorilere ilişkin örnek cümleler aşağıda alt temalara göre ayrılarak verilmiştir.

Farklı bir bakış açısı ve problem çözme alt temasına ilişkin örnek cümleler aşağıdaki gibidir:

(K17).

"Sanatla ilgilenmek, farklılıkları algılamamı, onlara saygı duymamı, açık fikirli olmamı sağlar."

"Sanatla ilgilenmek, bakış açımı çok yönlü biçimde değiştireceği için, her konuya daha farklı yönden yaklaşmam mümkün olur; beni düşünmeye, sorgulamaya ve araştırmaya yöneltir.."("K18).

"Sanatla ilgilenen insanlar, karşılaştığı olaylara daha farklı açıdan bakabildiği için, daha ince düşünceli ve çözüm odaklı olurlar." (K20).

"Sanat, bize yeni bakış açıları kazandırabilir, bu yüzden mesleki anlamda problem çözme becerimizi de besler."(K71).

"Sanat, öğretilmiş ve öğrenilmiş düşünme kalıplarının dışına çıkabilmemize yardımcı olur." (K87).

"Sanat, ufkumuzu genişleterek hayatta ve meslekte herhangi bir sorunla karşılaştığımızda çok yönlü bir şekilde çözümler üretmemizi sağlar." (K89).

Yaşam enerjisi, mutluluk, pozitiflik ve ruhsal dinginlik alt temasına ilişkin örnek cümleler aşağıdaki gibidir:

"Sanatla ilgilenen insanlar, meslekleri ne olursa olsun huzurlu ve mutlu bir ruh halinde olurlar ve bu hal, yaptıkları işlere de yansır." (K8).

"Sanatın her dalı insanın yaşamına anlam, zenginlik katar." (K35).

"Sanatla ilgilenmek, beni hayata daha sıkı bağlar ve pozitif enerji ile doldurur." (K39).

"Sanatla ilgili olmak, yaşamla ilgili olmak demektir. Sanatsız yaşam, tatsız bir yaşam olacaktır." (K44).

"Sanat dallarıyla iç içe olmak, ruhsal olarak arınmamıza yardım eder." (K64). 
"Sanat, ruhun zinde kalmasını sağlar, insanı yeniler, tazeler ve dinginleștirir. Renkli bir hayat sunar."(K73).

“... Sanat, karanlığı aydınlatan bir lambadır." (K105).

Kişisel gelişim ve kişisel kazanımlar alt temasına ilişkin örnek cümleler aşağıdaki gibidir.

"Sanatsal aktivitelerin, bireyin kendi gizil güçlerini keşfetmesinde önemli yeri olduğunu görüyorum; kişi kendini keşfedebilir ve duygu-düşünce açısından esneyebilir." (K3).

"...Sanat, estetik düşünüp olaylara da o şekilde yaklaşmamızı sağlar." (K20).

"Sanat, bireyin içinde gizli kalmış duyguları ifade etmeye aracı olur." (K23).

"Sanatla ilgilenmek, kendini gerçekleştirme ve kendini daha iyi ifade etmeye katkı sağlıyor."(K25).

"Sanatla ilgilenince, bireyin bakış açısı genişler ve empati becerisi gelişir." (K28).

"...Sanat, hoşgörüyü ve sabrı içinde barındırır." (K60).

"Sanat, insana ilham verir ve davranışlarını düzenler; olaylara farklı açılardan bakabilmeyi ve hoşgörülü olabilmeyi öğretir." (K90).

Yaratıcılık ve estetik düşünme alt temasına ilişkin örnek cümleler aşağıdaki gibidir:

"Sanatla ilgilenmek, uğraştığımız işe farklı yönlerden bakabilmemize, onu estetik yönüyle değerlendirebilmemize yardımcı olur." (K11).

"Sanat yoluyla estetik düşünebilir ve olaylara da estetik açıdan yaklaşmayı öğrenebiliriz."(K21).

"Sanatla ilgilenmek, estetik algımızı ve yaratıcılı̆ımızı geliştirir."(K24).

"Sanat, hayatın kendisine daha estetik bir açıdan bakmamızı sağlar."(K95).

"Sanata ilgisiz bir öğretmen, gerçekten öğretmen değildir. Daha yenilikçi, yaratıcı bir öğretmen olmak için sanat şart."(K109).

\section{Sanatın Kültürel, Sosyal ve Mesleki Gelişime Desteği Temasına ilişkin Bulgu, Yorum ve Örnek Cümleler}

İkinci temayı oluşturan dört alt temaya ilişkin betimsel bilgilere Tablo 10' da yer verilmiştir.

Tablo 10.

Sanatın kültürel, sosyal ve mesleki gelişime desteğine ilişkin yüzde ve frekans değerleri

\begin{tabular}{llrr}
\hline Tema & Alt tema & $\boldsymbol{f}$ & $\%$ \\
\hline Sanatın kültürel, sosyal & Kültürel birikim & 18 & 20 \\
ve mesleki gelişime & Verimlilik ve motivasyon & 12 & 13 \\
desteği & Sosyallik ve iletişim & 12 & 13 \\
& Mesleki katkı & 11 & 12 \\
\hline
\end{tabular}

Tablo 10'da görüldüğü gibi, \%20 oranında sanatla ilgili olmanın "kültürel birikim sağladığı" yönünde, \%13 oranında "verimlilik sağladığı" ve "motivasyonu arttırdığı" yönünde, \%13 oranında "sosyalleşmeyi sağladığı" ve "iletişim becerilerini arttırdığı" yönünde ve \%12 oranında "öğretmenlik mesleğine ilişkin olumlu katkı sağladığı" yönünde ifadeler kullanılmıştır.

Kültürel birikim alt temasına ilişkin örnek cümleler şu şekildedir:

"Sanatla ilgili olmak, kendi kültürel birikimimizi oluşturmamıza katkı sağlar." (K10). 
"Sanatın herhangi bir dalıyla ilgilenmek, bireye hem ruhsal hem de kültürel olarak katkı sağlar ve bu sayede toplumun refah seviyesinin yükselmesine de yardımcı olur." (K25).

"Sanatla ilgili olmak, öncelikle bireysel olarak bilgi ve genel kültür birikimimizi artırır." (K49).

"...Sanat dallarıyla iç içe olmak sayesinde artan kültürel birikimimizle, öğrencilerimize daha geniş bir ufuk sunabilme şansımız olur." (K64).

"Sanat, bizleri düşünsel ve kültürel anlamda daha zengin bir birey haline getirir, kavrayış kapasitemizi arttırır." (K92).

"Sanat, kültürün önemli bir parçasıdır ve bu sebeple farklı kültürleri tanımamızda ve tanıtmamızda yardımcı olur." (K103).

Verimlilik ve motivasyon alt temasına ilişkin örnek cümleler aşağıdaki gibidir:

"Sanat, ruhumuzun gıdasıdır ve biz kendimizi iyi hissedersek, mesleki motivasyonumuz da yüksek olur."(K38).

"Sanat dallarıla iç içe olmak, ruhsal arınma için iyi bir aracı olarak mesleki motivasyonumuzu arttırabilir." (K64).

"Sanat, her açıdan insanın ufkunu açan bir faktör ve bu sayede verimliliği ve yaratııılığı da attırIyor." (K91).

"Sanatla ilgilenmek, motivasyonumuzu arttırarak başarımıza katkı sağlar." (K96).

"Sanat dallarından herhangi biriyle bile ilgilenmek, insan ruhuna iyi gelir; eğer daha verimli bir çalışma hayatı istiyorsak en az bir sanat dalıyla ilgilenmek gerekli." (K112).

Sosyallik ve iletişim alt teması ilişkin örnek cümleler aşağıdaki gibidir:

"Sanatla iç içe olmak, kişiler arası ilişkileri yoğunlaştırır, kültürel anlamda daha zengin bir yaşam ve çevre olanağı sunar." (K4).

"Sanat, kendini farklı yollarla ifade edebilme olanağı sunduğu için sosyalleşmenin de önünü açar." (K5).

"Sanat, bizi sosyal hayata daha sıkı bağlar." (K39).

"Sanatla ilgili olan kişi, farklııklara duyarlı olur; bu da çevresi ile olan iletişimini kuvvetlendirir." (K82).

Mesleki katkı alt temasına ilişkin örnek cümleler aşağıdaki gibidir:

"Sanatın farklı dallarıyla ilgilenmem, meslek yaşantımda kendime daha çok güvenmemi sağlar ve yapabileceklerimin sınırsızlığını bana gösterir." (K1).

"Sanatın herhangi bir dalı ile ilgilenmek, mesleki hakimiyetimizi geliştirir, daha geniş ve aydın bir mesleki bakışa sahip olmamızı sağlar." (K7).

"... Sanat sayesinde huzurlu ve mutlu bir ruhsal yaşantı süreriz ve bu mesleki yaşantımıza da yansır; mesleğini mutlulukla yapan insanlar toplumu ve insanlığı bir üst noktaya taşıyacaklardır." (K8).

"Sanat, kişinin yaptığı işi bir külfet değil, bir başarı, yaşamının bir amacı olarak görmesini sağlar." (K22).

"Sanatla ilgilenen bir branş öğretmeni, öğrencilerine de sanatı sevdirebilir." (K72).

\section{Sanatın Öğretme Eyleminin Niteliğinin Yükselmesine ve Insanlığa Katkısı Temasına ilişskin Bulgu, Yorum ve Örnek Cümleler}

Üçüncü temayı oluşturan iki alt temaya ilişkin betimsel bilgilere Tablo 11'de yer verilmiştir.

Tablo 11. 
Sanatın öğretme eyleminin niteliğinin yükselmesine ve insanlığa katkısına ilişkin yüzde ve frekans değerleri

\begin{tabular}{|c|c|c|c|}
\hline Tema & Alt tema & $f$ & $\%$ \\
\hline $\begin{array}{l}\text { Sanatın, öğretme } \\
\text { eyleminin niteliğinin }\end{array}$ & Topluma ve gelecek nesillere kültürel aktarım & 12 & 13 \\
\hline $\begin{array}{l}\text { yükselmesine ve insanlığa } \\
\text { katkısı }\end{array}$ & Nitelikli öğrenme & 19 & 21 \\
\hline
\end{tabular}

Tablo 11'de görüldüğü üzere, \%21 oranında, sanatla ilgili olmanın "nitelikli bir öğrenmeye katkı sağladığı" yönünde, \% 13 oranında "topluma ve gelecek nesillere kültürel aktarıma katkı sağladığı" yönünde görüş bildirilmiştir.

Topluma ve gelecek nesillere kültürel aktarım alt temasına ilişkin örnek cümleler aşağıdaki gibidir:

"... Gelecek nesillere gerçek bir miras bırakmak için, sanatı sonsuzca benimseyip öğrenip öğretmeye devam etmek gerek." (K4).

"Sanat geleceğin temelidir, aydınlığa giden yolda en büyük umuttur. Ne kadar çok insanı içine çekerse, o kadar uygar bir toplum olacağımıza inanıyorum." (K12).

"... Sanatsız bir toplum düşünülemez; bizler öğretmenler olarak sanatla iç içe olursak gelecek nesillere de bunu aktarabiliriz." (K36).

"... Sanatla ilgilenmek, öğrencilerime daha iyi bir bilgi birikimi ve kültürel aktarım için önemlidir." (K44).

"Sanatla ilgilenmek, daha bilinçli ve kültürlü nesiller yetiştirmemize yardımcı olur." (K78)

"... Toplumu kalkındırmak bizim elimizde; biz öğretmenler olarak öğrencilerimizde sanatla farkındalık oluşturabilirsek, toplum için en iyisi olur." (K100).

Nitelikli öğrenme alt temasına ilişkin örnek cümleler aşağıdaki gibidir:

"... Sanatla ilgili bir öğretmen, öğrencilerinin kendilerini keşfetmelerini ve gerçekleştirmelerini, gizil güçlerinin farkına varmalarını sağlayabilir." (K3).

"Sanatla ilgili bir öğretmen olmak, renkli bir öğrenme ortamı sunarak öğrencilerin derse daha ilgili olmasını sağlayabilir." (K70).

"Öğretmenliğimde, ilgilendiğim sanat dallarına başvurarak dersin içeriğini zenginleştirebilir, öğrencilerin ilgisini canlı tutabilirim." (K93).

"... Sanat ile kendi branş dersimi birleştirerek materyal hazırlayabilir, dersimi daha aktif hale getirebilirim." (K94).

"... Bir öğretmen olarak sanatla iç içe olduğumda, öğrencilerimde sanata ve kültürel aktivitelere ilişkin farkındalık uyandırabilirim. Öğretim yöntemlerime ve materyal tasarımıma sanat dallarını katabilirim." (K103).

“... Derslerimde sanatla ilişki kurarak öğrenmenin kalıcılığını arttırabilirim." (K111).

"... Sanatın herhangi bir dalıyla ilgilenmek, bir öğretmen olarak iyi bir rol model olmamızı sağlar ve öğrencilerimizin sanata ilgilerini belirlemeleri için yol gösterici olabiliriz." (K113).

\section{Tartışma}

Bilgi çağında öğretmen, öğrencilerinin yalnızca bulunduğu döneme uyumlanmalarına rehberlik etmenin ötesinde, onları çağın gerekliliklerinin de ötesine geçmeye, çok yönlü düşünmeye, sorgulayıcı 
ve eleştirel bir bakış açısı benimsemeye, empati ve duyarlıık becerilerini geliştirmeye, kendilerine, çevrelerine ve dünyaya estetik bir tavırla yaklaşabilmeye yönlendirmekle sorumludur. Bu sorumluluğu yerine getirebilmek için, bir rol model ve rehber olarak öncelikle kendini yetiştirmesi ve kültürel bağlamda donatması gereklidir.

Schiller (2020: 47), kişiliğin asilleştirilmesini, ruhun yücelişini bir amaç olarak ele alır ve bu görüşünü şöyle vurgular: "Bir eğitim ülküsü olarak ruh yüceliği”. Bu amaç doğrultusunda, insanlığı her türlü siyasi yıkımda "saf ve berrak" kalabilen kaynaklara götüren bir araca olan gereksinimden söz eder ve şöyle der: "Bu araç, güzel sanattır, bu kaynaklar sanatın ölümsüz örneklerinden fışkırır." Sanatla olan ilişkimiz, estetik algımızın gelişimini belirler. İnsan ilişkilerinden doğa ile etkileşimimize, dünyayı algılayışımızdan yasalara ve devlet olgusuna kadar yaşama ilişkin her alanda süren güzeli arayışımızda vazgeçilmez aracımızdır. Bu aracı en etkin biçimde kullanabilmenin yolu, nitelikli ve kapsamlı, ayrıştırmak yerine bütünleştiren bir eğitim anlayışından geçer.

Bilim ve sanatın ilişkisi üzerine yapılan çalışmalarda Nobel ödüllü bilim insanlarının, müzik yapma, görsel sanat eseri (resim, heykel vb.) üretme, şiir yazma ve yaratıcı yazma, aktörlük yapma oranlarının diğer bilim insanlarına göre anlamlı derecede fazla olduğu sonucuna varılmıştır. Yine ilgili bir araştırmada, Nobel ödüllü ve Ulusal Bilim Akademisi üyesi bilim insanlarının, yetişkin hobilerinin sayısı ve türüyle, bir bilim insanı olarak elde ettikleri başarılar arasında olumlu yönde anlamlı korelasyonlar bulgulanmıştır. Özellikle sanat koleksiyonculuğu, fotoğrafçılık ya da müzisyenlik yapan ve aktif olarak sanatla bir arada olan bilim insanlarının, diğer meslektaşlarına göre daha üretken oldukları ve çok daha fazla alıntı yapılan bilimsel yayınlar ürettikleri görülmüştür. Bir bilim insanı ne kadar çok sanatsal hobi edinmişse, bilimde saygınlık kazanma olasılığının o kadar arttığı sonucu vurgulanmıştır (Root-Bernstein\&Root-Bernstein, 2004).

Bilim insanlarının bilişsel tarzlarının, sanatsal hobilerinin türüyle ilişkili olduğu bulgusu da aynı derecede ilgi çekicidir. Görsel sanatlar ve müzikle uğraşanların, özellikle görsel ve kinestetik olmak üzere çeşitli düşünme biçimlerini, edebiyatla ilişkili hobileri olanlara göre önemli ölçüde daha yüksek oranlarda kullandıkları, yazarlığı hobi edinenlerin sözel kalıplarla düşünme eğiliminde, heykeltıraşların ise dokunsal ve hareket odaklı düşünme eğiliminde oldukları belirtilmiştir. Tüm bu nedenlerle, en yaratıcı bilim insanlarının, birer sanatçı gibi sanatı yaşamlarına kattıkları vurgulanmıştır (RootBernstein\&Root-Bernstein, 2004).

Bu farkındalıklardan hareketle, nitelikli bir öğrenme ortamının sağlanabilmesi için, öğretmeyi misyon edinmiş eğitimcilerin bilimi ve sanatı, meslek bilgisini ve sanatsal hobileri birbirinden ayırmaktansa, bütüncül bir yaklaşımla ele almaları önemlidir. Sanatı, öncelikle kendi kişisel ve mesleki yaşantılarına ve sonrasında birer rol model olarak, yetiştirdikleri nesillerin yaşantılarına daha çok katmalarının önem taşıdığı söylenebilir.

\section{Sonuç ve Öneriler}

Öğretmen adaylarının sanatın katkılarına ilişkin görüşlerinde öne çıkan vurgular ve buradan hareketle ulaşılan temalar Şekil 1, Şekil 2 ve Şekil 3’te görülmektedir: 


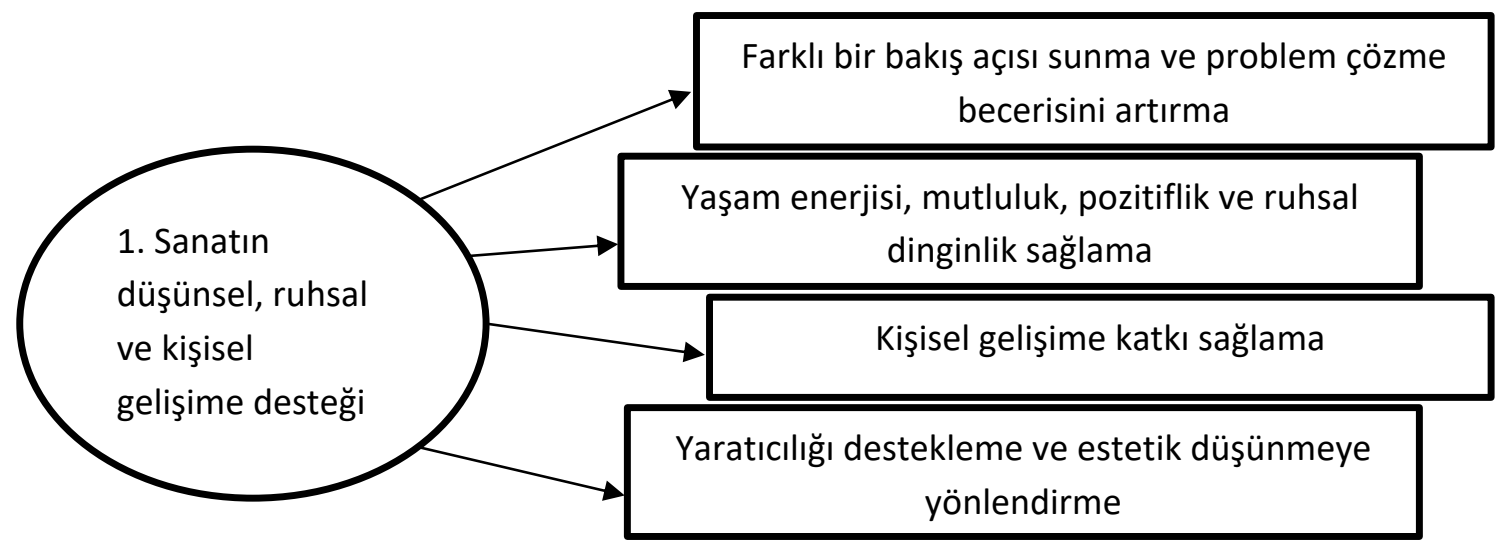

Şekil 1. Birinci tema ve alt temalar

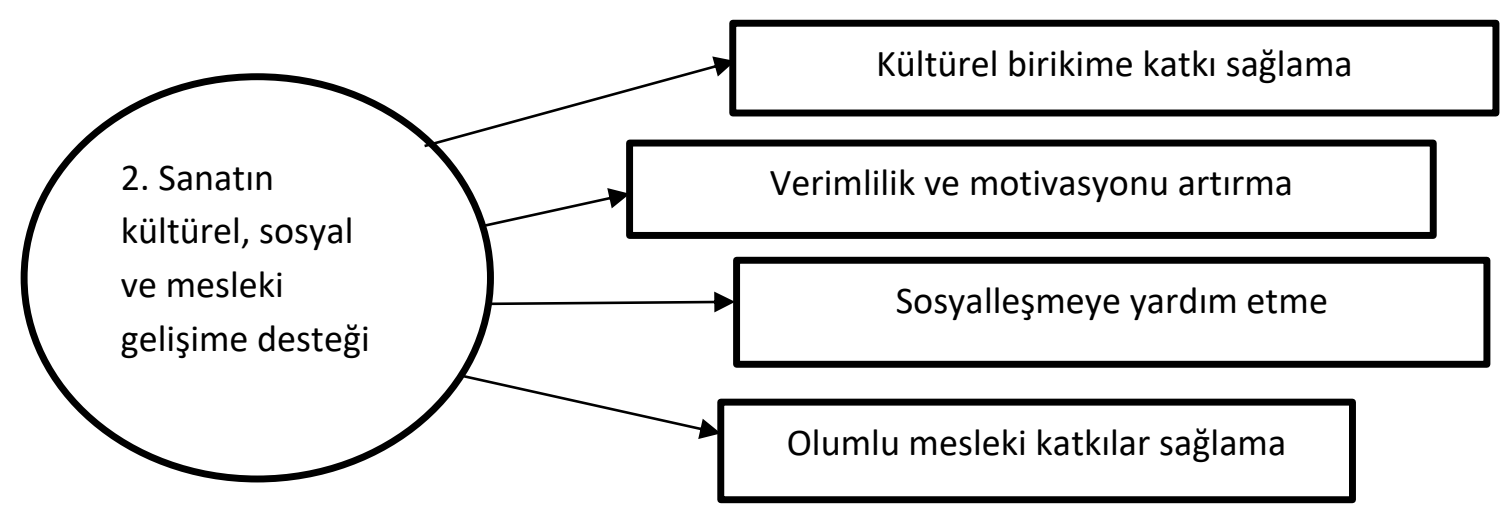

Şekil 2. İinci tema ve alt temalar

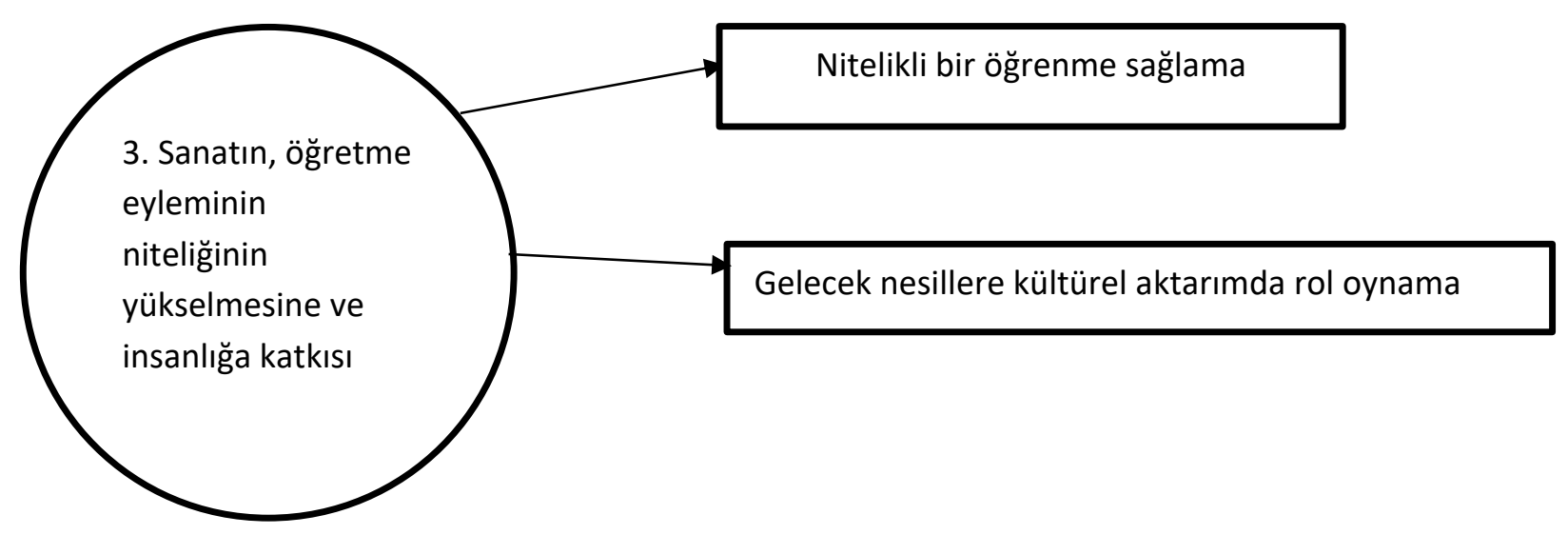

Şekil 3. Üçüncü tema ve alt temalar

Sanatın bu çok yönlü desteğinden en yüksek seviyede yararlanabilmek için, onu kişisel yaşamlarımıza etkin biçimde katmak gereklidir. Kuşkusuz her bireyin ilgi alanı, eğilimleri ve becerileri farklı yönlere uzanabilir; bu nedenle her bireyin her sanat alanına ilgi duyması ve kendini bu yolla ifade etmesi beklenemez. Ancak, öğretmenlik mesleği özelinde bakıldığında, sanatla ilişki kurmak için çaba göstermek, farklı alanları deneyimlemeye açık olmak, bu alanlara merak duymak, bu alanların güçlü 
yönlerinden yararlanmaya çalışmak, kişisel ilgi duymanın ötesinde, mesleki bir sorumluluk dahilinde düşünülebilir. Estetik düşünebilmenin, estetik tavır ve yargı geliştirebilmenin yolu, sanatla kurulan yakın ilişkiden geçer.

Çalışma bulgularına bakıldığında, katılımcı öğretmen adaylarının \%53'ünün konser etkinliklerine yılda bir kez katıldığı ya da hiç katılmadığı, \%30'unun hiçbir sanat alanında amatör bir atölye katılımı gerçekleştirmediği, \%82'sinin yılda bir kez tiyatro oyunu izlediği ya da hiç izlemediği, \%88'inin yılda bir kez bir görsel sanat sergisini ziyaret ettiği ya da hiç etmediği, \%89'unun yılda bir kez opera/bale/dans temsili izlediği ya da hiç izlemediği ve \%90'ının yılda bir kez bir edebiyat/felsefe/şiir söyleşisine katıldığı sonucuna ulaşıımıştır.

Çalışma sonuçları, katılımcıların Türkiye'nin üçüncü büyük şehrinde ve sanatsal etkinliklerin çok çeşitlilikte, ulaşılabilirlikte olduğu bir sanat şehrinde öğrenimlerine devam ettikleri göz önünde bulundurulduğunda, sanatın çok yönlü katkıları olduğunu belirtmelerine rağmen, farklı sanat alanlarına yaşamlarında yeterince yer açamadıkları ve bütünsel anlamda sanatla ilişkilerinin yüzeysel kaldığı yönündedir. Sanatla bütünleştirilen bir öğretmen eğitimi, sanatla bağ kurmayı kişisel çabaların ötesine geçirecektir. Birer rol model olacak olan geleceğin öğretmenlerinin, dünyaya farklı bir perspektiften bakacak nesiller yetiştirebilmeleri için hem kendilerini, hem de öğrencilerini sanatla donatması beklenir. Bu açıdan bakıldığında;

- Öğretmen yetiştirme programlarının bütüncül bir yaklaşımla yeniden ele alınması,

- Farklı sanat alanlarında seçmeli derslerin olduğu bir havuz oluşturulması,

- Bu havuzda müzik toplulukları, drama, resim, heykel, seramik, fotoğrafçılık, yaratıcı dans, tiyatro, yaratııı yazarlık, el sanatları gibi derslerin yer alması ve gerektiğinde farklı fakültelerle işbirliği içinde çalışılması,

- Öğretmen adaylarının lisans eğitimi süresince, program çerçevesinde önceden belirlenmiş bir sayıda seçmeli sanat dersini lisans eğitimi süresinde almakla yükümlü olmaları,

- Edebi eser okumanın bir boş zaman aktivitesi olmasının ötesinde, öğretmenlik mesleği için gerekli bir alışkanlığa dönüşebilmesinin desteklenmesine yönelik, bir eğitim-öğretim dönemi içinde belirlenmiş sayıda ve türde kitapların okunmasının bir ders yükümlülüğü olarak ele alınması,

- Farklı disiplinlerde ve farklı üniversitelerde öğrenim gören öğretmen adaylarııın sanatla olan ilişkilerini ortaya koymak amacıyla benzer çalışmaların yapılması önerilebilir. 


\section{Kaynakça}

Arıkan, R. (2005). Araştırma Teknikleri ve Rapor Hazırlama. Asil Yayın Dağıtım: Ankara.

Arnheim, R. (2007). Görsel Düşünme. ( R. Öğdül, Çev.). İstanbul:Metis Yayınları.

Atalmış, E.H. (2019). Araştırma Yönteminin Seçimi. S. Şen ve i. Yıldırım (Ed), Eğitimde Araştırma Yöntemleri içinde (ss. 97-115). Ankara: Nobel Akademik Yayıncılık.

Cansoy, R. ve Türkoğlu, M.E. (2019). Verilerden Anlam İnşa Etme Süreci. S. Turan (Ed), Eğitimde Araştırma Yöntemleri içinde (ss. 129-159). Ankara: Nobel Akademik Yayıncılık.

İlhan, A. Ç. (1997). Illköğretimde Sanat Eğitimi ve Eğitsel Drama. Yaşadıkça Eğitim, 54, 17-21.

Özcan, M. (2011). Bilgi Çağında Öğretmen Eğitimi, Nitelikleri ve Gücü: Bir Reform Önerisi. Ankara: TED iktisadi İşletmesi.

Read, H. (1981). Sanat ve Toplum. (S. Mülayim, Çev.). Ankara: Umran Yayınları.

Robinson, K. (2008). Yaratıcılık: Aklın Sınırlarını Aşmak. (N. G. Koltaş, Çev.). İstanbul: Kitap Yayınevi.

Root-Bernstein, R. \& Root-Bernstein, M. M. (2004). Artistic Scientists and Scientific Atrists: The Link Between Polymathy and Creativity. R. J. Sternberg, E. L. Grigorenko, \& J. L. Singer (Ed), Creativity: From potential to realization içinde (ss. 127-151). American Psychological Association. doi: 10.1037/10692-008

Schiller, F. R. (2020). Insanın Estetik Eğitimi Üzerine. (G. Aytaç, Çev.). Ankara: Folkitap.

Şahin, A. (2011). Öğretmen Algılarına Göre Etkili Öğretmen Davranışları. Ahi Evran Üniversitesi Eğitim Fakültesi Dergisi,12(1), 239-259.

Wilson, V. (2011). Research Methods: Content Analysis. Evidence Based Library and Information Practice, 6.4, 177-179. doi: 10.18438/B8CG9D 